7. Матеріали міжнародної науково-практичної конференції «Міжкультурний діалог у сучасній освіті», 11 листопада 2008 р. - К. : Видавець СПД Цудзинович. - Т.І., 2009. $-96 \mathrm{c}$.

8. Поштарева Т. В. Формирование этнокультурной компетентности Т. В. Поштарева // Педагогика. - 2005. - № 3. - С. 35-42.

9. Тодорцева Ю. В. Педагогіка толерантності: [методичні рекомендації] / Ю. В. Тодорцева. - Одеса : СВД Черкасов М. П., 2004. - 90 с.

10. Якса Н. В. Толерантність в системі ціннісно-цільових пріоритетів педагогічної освіти: полікультурний аспект / Н.В.Якса // Вісник Житомирського державного університету імені Івана Франка. - Житомир, 2007. - Випуск 34. - С. 102-105.

Стаття надійшла до редакції 25.05.2012 p.

\title{
МОДЕЛЬ ПІДГОТОВКИ МАЙБУТНІХ УЧИТЕЛІВ ТЕХНОЛОГІЙ ДО ВИКОРИСТАННЯ КОМП'ЮТЕРНОЇ ТЕХНІКИ У ПРОЦЕСІ ВИВЧЕННЯ ФАХОВИХ ДИСЦИПЛІН
}

\footnotetext{
Терещенко С. П. Модель підготовки майбутніх учителів технологій до використання комп 'ютерної техніки у прочесі вивчення фахових дисииплін.

У статті розглянуто проблему використання комп'ютерної техніки майбутніми вчителями технологій у прочесі вивчення фахових дисциплін, визначено модель підготовки майбутніх учителів технологій до використання комп'ютерної техніки.

Ключові слова: комп 'ютерна техніка, модель підготовки майбутніх учителів технологій.

Терещенко С.П. Модель подготовки будущих учителей технологии к использованию компьютерной техники в процессе изучения специального дисииплин.

В статье рассмотрена проблема использования компьютерной техники будущими учителями технологии в процессе изучения специильных дисциплин, определена модель подготовки будущих учителей технологии к использованию компьютерной техники.

Ключевые слова: компьютерная техника, модель подготовки будущих учителей технологии.

Tereshchenko S. Model of training future teachers of technologies to using the computer technics in the process of studing professional disciplines.

The article deals with the problem of using the computer technics by the future teachers of technologies in the process of studying of specialized disciplines, it is defined the model of training future teachers of technologies to using the computer technics.

Key words: computer technics, model of training future teachers of technologies.
}

Актуальність дослідження. Підготовка педагогічних кадрів у сфері технологічної освіти в нашій країні отримала широке розповсюдження: майже кожен освітній заклад потребує високоосвічених фахівців цієї кваліфікації. Сьогодні актуальним є питання підвищення рівня освіченості вчителів технологій, у цьому напрямі ведуться активні пошуки: розробляються нові кваліфікаційні характеристики фахівців, визначаються професійні якості особистості вчителя, удосконалюються навчальні плани i програми, готуються нові підручники та навчальні посібники. Вища школа сьогодні, насамперед - педагогічна, орієнтується у своєму розвитку на якісну 
підготовку компетентного й конкурентоздатного фахівця, що відповідає змінам, які відбуваються на світовому ринку праці й освітніх послуг [6].

Нині ми маємо чітко окреслену законодавчу базу вищої освіти: Закони України «Про вищу освіту» та Національну доктрину розвитку освіти, у яких відображено тенденції оновлення змісту, форм і методів професійної підготовки педагогічних працівників на основі прогресивних концепцій та запровадження інноваційних технологій [3].

Тому актуальною постає проблема вдосконалення змісту i форм підготовки майбутніх учителів технологій, забезпечення їхньої готовності до майбутньої професійної діяльності.

Одна із тенденцій розвитку освіти передбачає активне впровадження в навчання нових комп'ютерних технологій, тому майбутньому вчителю технологій необхідно орієнтуватися і вміло використовувати комп'ютерну техніку та комп'ютерні технології як у навчанні, так і в майбутній професійній діяльності.

Підготовкою майбутніх учителів технологій 3 використанням комп'ютерної техніки опікувалися Р. Гуревич, Г. Нітченко, І. Повечера, О. Торубара. У працях науковців В. Кондратюка, I. Нищака, В. Сидоренка та інших з'ясовуються окремі напрямки використання комп'ютерів у процесі підготовки вчителів технологій.

Нині відсутня дидактично обгрунтована стратегія використання комп'ютерної техніки в процесі підготовці майбутніх учителів технологій під час вивчення фахових дисциплін.

Мета статті полягає у визначенні структурних елементів моделі підготовки майбутніх учителів технологій до використання комп'ютерної техніки в процесі вивчення фахових дисциплін.

Виклад основного матеріалу. Традиційне навчання у вищому навчальному закладі з його усталеними, стандартними формами, методами, засобами, змістом, цілями й завданнями навчання, постійним зменшенням аудиторних годин з фахових дисциплін не дозволяє збільшити обсяг успішно засвоюваного матеріалу в аудиторний час занять, а опрацювання його самостійно, без пояснення викладачів не дасть суттєвих результатів.

Позитивна роль комп'ютерної техніки зумовлена тим, що вона $\epsilon$ потужним знаряддям, за допомогою якого студент реалізує поставлені завдання. Розв'язання завдань за допомогою комп'ютера звільняє від шаблонних, однотипних операцій, збільшуючи обсяг засвоєного матеріалу. Успішне використання комп'ютерної техніки сприяє розвитку у студента мислення, пам'яті, здатності до самоорганізації та співтворчості, підвищує навчальну мотивацію, а отже і рівень його фахової підготовки.

3 іншого боку, не можна не констатувати негативних наслідків, пов'язаних iз широким упровадженням комп'ютерних технологій у навчальний процес. Поряд із посиленням компонентів професійної підготовки за допомогою використання комп'ютерних технологій може спостерігатися явно протилежна тенденція. Результати досліджень, 
проведених вітчизняними i зарубіжними науковцями, переконливо засвідчують, що за надмірного спрощення розв'язання завдань за допомогою комп'ютерної техніки зростає частка таких операцій, які ведуть до зниження рівня інтелектуальних здібностей людини.

Отже, комп'ютерна техніка та відповідне програмне забезпечення не повинні замінювати основні функції викладача: розвиток особистості студентів, творчий пошук задля організації їхньої спільної роботи, підбору, розроблення й вибору навчальних програм. Викладач визначає навчальну мету заняття, масштаби застосування комп'ютерної техніки з урахуванням рівня знань, умінь з певної дисципліни та готовність до використання, раціонально розподіляє інформацію, яку необхідно вивчити, між педагогом, підручником та комп'ютером, що повинно сприяти ефективній підготовці фахівців. Викладач вирішує, на яких етапах заняття застосування комп'ютерної техніки має сенс і які саме програми треба запропонувати студентам. Лише продумана комбінація застосування елементів комп'ютерного навчання та живого спілкування на заняттях дозволить викладачеві досягти поставленої мети.

Для того щоб оцінити комп'ютерні технології через призму педагогічної доцільності, вони повинні задовольняти мету та завдання навчання; ураховувати специфіку і зміст навчального предмета, а також необхідний рівень формування знань, умінь і навичок як з позиції вивчення та засвоєння конкретної дисципліни, так і з позиції професійної необхідності та значимості комп'ютеризованих курсів; допускати варіацію рівня проблемності і складності завдань та екранного подання інформації студентам; передбачати різні форми організації занять 3 використанням засобів комп'ютерної техніки; давати можливість здійснювати контроль за діяльністю студентів, фіксацію та аналіз результатів контролю i мати відповідний інтерфейс; ураховувати психоемоційні та вікові особливості студентів i рівень їх розумового розвитку; допускати конфігурування системи, варіацію і генерування завдань; допомагати викладачеві у перевірці правильності виконання завдань [7, с.123-125].

Отже, підготовка майбутнього вчителя технологій 3 використанням комп’ютерної техніки передбачає побудову певної моделі.

Відповідно до тлумачення у філософському словнику А. Грицанова під моделлю (від modulus - мірило, зразок) розуміємо об'єкт-замісник, який у визначених умовах може заміняти об'єкт-оригінал, відтворюючи властивості, що цікавлять, і характеристики оригіналу [5, с. 435].

Науковці В. Штофф та О. Антонова визначають модель як систему, яка відображає й відтворює об'єкт дослідження та здатна замінити його так, щоб вивчення цієї системи надало нам нову інформацію про об'єкт [1, с.51].

Моделювання $є$ основною категорією теорії пізнання, на якій грунтуються теоретичні й експериментальні методи наукового дослідження. Розробка моделі зумовлена необхідністю удосконалення процесу підготовки майбутніх учителів технологій до використання комп'ютерної техніки в процесі вивчення фахових дисциплін. 
В основу моделювання покладено операцію абстрагування. Завдяки цій операції на базі структури та функції створюється образ досліджуваного об'єкта у формі графічних таблиць і схем, математичних формул тощо.

Моделювання дає змогу наочно уявити об'єкт, проникнути в його глибину, розпізнати складові елементи й описати важливі теоретичні питання досліджуваної проблеми.

Відповідно до підходу, розробленого Ю. Бабанським [2, с.95-98], який ми взяли за основу, до структури моделі обов'язково повинні входити такі підструктури: концептуальні (принципи, умови); нормативні (мета, зміст, критерії); технологічні (методи і форми). Отже, основними структурними компонентами розробленої моделі є: мета, завдання, умови, методи, форми навчання, рівні готовності і результат.

Розроблена нами модель забезпечує виконання всіх визначених вимог та має за мету підвищення рівня знань та вмінь майбутніх учителів технологій 3 фахових дисциплін за допомогою застосування сучасної комп'ютерної техніки. Графічне зображення моделі застосування комп'ютерної техніки у фаховій підготовці майбутніх учителів технологій подано на рис. 1.

Структурні компоненти моделі спрямовано на формування належного (достатнього та високого) рівня знань та умінь майбутніх учителів технологій з фахових дисциплін засобами комп'ютерної техніки.

Модель підготовки майбутніх учителів технологій з використанням комп'ютерної техніки включає три компоненти: змістовний, оцінний і комунікативний. Змістовний компонент характеризує види комп'ютерних технологій; оцінний компонент містить вимоги щодо застосування комп'ютерної техніки у навчальному процесі; комунікативний визначає форми взаємодії викладача, студента і засобів комп'ютерних технологій у фаховій підготовці майбутніх учителів технологій, мотиваційний визначає процес формування потреби у використанні комп'ютерної техніки. Визначення основних компонентів моделі здійснювалося шляхом вивчення наукової літератури, ознайомленням з практикою використання комп'ютерної техніки, проведенням експериментальної роботи. Усі сформульовані компоненти впливають на процес фахової підготовки і знаходяться у безпосередньому взаємозв'язку між собою.

Для ефективного використання комп'ютерної техніки майбутніми вчителями технологій було визначено педагогічні умови застосування комп'ютерної техніки. Педагогічні умови - це категорія, яка визначається як система певних форм, методів, матеріальних умов, реальних ситуацій, що об'єктивно склалися чи суб'єктивно створені, необхідних для досягнення конкретної педагогічної мети [4, с.100-102].

До педагогічних умов ми віднесли: готовність до використання комп'ютерних технологій, що включає в себе сформованість чотирьох компонентів: мотиваційного, операційно-діяльнісного, рефлексивного та когнітивного; забезпечення інноваційної спрямованості навчання та формування пізнавальної самостійності. 


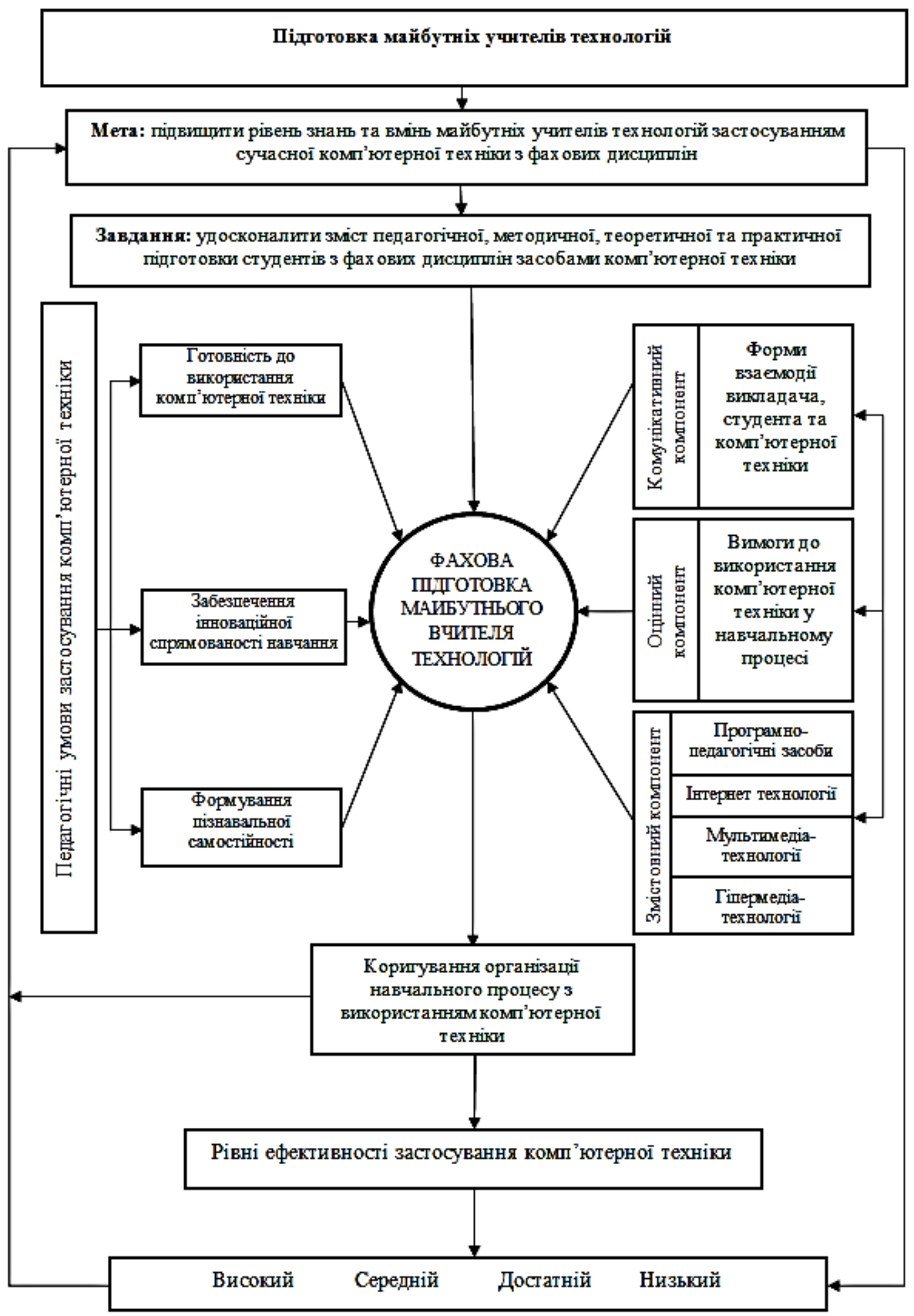

Рис. 1. Модель підготовки майбутніх учителів технологій до застосування комп 'ютерної техніки у процесі вивчення фахових дисциплін 
Для перевірки виконання зазначених педагогічних умов нами було проведено констатувальний експеримент, який включав анкетування, спостереження, бесіди тощо.

Використання комп'ютерної техніки відбувається в різних формах навчально-виховної діяльності: під час читання лекцій, проведення практичних, лабораторних занять. Комп'ютерна техніка використовувалася як демонстраційний засіб, джерело інформації, як засіб для моделювання наукових експериментів. Це надало змогу зменшити витрати часу на виконання шаблонних операцій, а отже, збільшити обсяг вивченого та засвоєного матеріалу.

При виборі програмного забезпечення, яке буде використовуватися студентами, необхідно враховувати такі вимоги [6]:

- матеріали програмного забезпечення мають бути науково викладені, написані доступною мовою для студента залежно від його спроможності сприймати цей матеріал;

- педагогічне програмне забезпечення повинно відповідати науковим, педагогічним, методичним, технічним вимогам;

- зручність інтерфейсу, легкість у користуванні, наявність системи підказок для роботи з програмою;

- відповідати всім вимогам санітарно-гігієнічних та ергономічних норм;

- структура програмного забезпечення має містити не тільки інформаційне наповнення, а й вимагати від студента певної співпраці опрацювання відповідей на поставлені запитання, виправлення помилок тощо;

- надавати викладачеві протокол роботи кожного студента 3 виведенням на екран або принтер та вести базу даних відповідей;

- коректно працювати з іншими програмними забезпеченнями.

Після вивчення певного обсягу матеріалу необхідно перевірити ефективність засвоєння знань та умінь майбутніми вчителями технологій 3 фахових дисциплін засобами комп’ютерної техніки.

Залежно від рівня сформованості готовності вчителя інформатики до профільного навчання ми виокремлюємо чотири рівні:

1. Адаптаційний (низький) рівень властивий студентам, які володіють низьким рівнем знань 3 предметів професійного спрямування; відсутність самостійності в навчальній діяльності; слабкий рівень контролю, самоконтролю та корекції власної професійної діяльності; виявляє незадоволеність вибором професії, слабкий рівень усвідомлення цілей сформованості майбутньої професійної діяльності з фізико-математичним профілем.

2. Елементарний (середній) рівень характеризується пасивним та епізодичним ставлення до професійної діяльності; фрагментарні та несистематичні знання 3 предметів професійної спрямованості; 3'являється потреба в самовдосконаленні лише за наявності появі труднощів у професійній діяльності; зазнає труднощів під час планування, контролю та самокорекції своєї педагогічної діяльності. 
3. Частково-пошуковий (достатній) рівень відрізняється переважно емоційно-позитивним ставленням до професійної діяльності; яскраво виявляються знання з фахових дисциплін; прогнозування, здатність оцінити та відкоригувати свою професійну діяльність; здатність до саморозвитку та самодіагностики; самооцінка власних можливостей не завжди $є$ адекватною.

4. Творчо-дослідницький (високий) рівень характеризується: чітким позитивним ставленням до професійної діяльності; умінням знаходити рішення в нестандартних ситуаціях; високим рівнем знань 3 фахових дисциплін; потребі в педагогічному самовдосконаленні та розвитку особистості, поглибленні теоретичних та методичних знань; адекватній самооцінці та високим рівнем самостійності.

Визначення рівня відбувалося проведенням тестування студентів 3 відповідних тем фахової дисципліни. У процесі експериментальної роботи ми проводили контрольні зрізи, після закінчення кожного з трьох умовних етапів, що відповідали певному компонентові професійної компетентності для з'ясування динаміки рівнів їх сформованості.

Висновки. Запропонована нами структурно-функціональна модель підготовки вчителя інформатики розкриває особливості структурних елементів, етапи підготовки, послідовний зв'язок цих елементів, в цілому особливості організації змісту підготовки майбутнього вчителя технологій засобами комп'ютерної техніки. Розроблена модель $є$ відкритою, постійно розвивається та за необхідності може бути доповненою новими елементами.

Перспектива подальших досліджень полягає в перевірці ефективності запропонованої моделі та коригування її змістових модулів.

\section{Література}

1. Антонова О. Є. Базові знання з педагогіки: становлення, розвиток, технологія формування : [монографія] / О. Є. Антонова. - Житомир: ЖДПУ, 2003. - 208 с.

2. Бабанский Ю. К. Научная организация педагогического процесса на основе его интенсификации и оптимизации. - В кн. : Педагогика / под ред. Ю. К. Бабанского. - М. : Педагогика, 1988. - 268 с.

3. Закон України про вищу освіту. Відомості Верховної Ради України. - 2002. № 20. -134 c.

4. Нагаєв В. М. Методика викладання у вищій школі: [навч. посіб.] / В. М. Нагаєв.- К.: ЧП, 2007. - 211 с.

5. Новейший философский словарь / [сост. А. А. Грицанов]. - Мн.: Изд. В. М. Скакун, 1998. - 896 с.

6. Обрізан К. Використання інформаційних та комунікаційних технологій у загальноосвітніх закладах / К. Обрізан // Інформатика. - 2003. - № 36. - С. 7-10.

7. Підготовка майбутнього вчителя до впровадження педагогічних технологій: [навч. посіб.] / О. М. Пєхота та ін. - К. : А.С.К., 2003.- 240 с.

Стаття надійшла до редакції 12.04.2012 p. 